\title{
PELAKSANAAN PAKET KONTEN UNTUK GURU BIMBINGAN DAN KONSELING DI SEKOLAH MENENGAH ATAS KABUPATEN KUBU RAYA
}

\author{
Amelia Atika $^{1}$, Novi Andriati ${ }^{2}$ \\ 1,2, Program Studi Bimbingan dan Konseling Fakultas Ilmu Pendidikan dan Pengetahuan Sosial \\ IKIP-PGRI Pontianak, Jalan Ampera No. 88 Pontianak \\ 1e-mail: ameliaatika200799@gmail.com
}

\begin{abstract}
Abstrak
Pelaksanaanpaket konten ini bertujuan untuk memfasilitasi para guru dan siswa dalam rangka membantu perkembangan dalam setiap aspek pada fase perkembangan siswa. Tujuan dari pengabdian ini adalah:1) Memfasilitasi dan menstimulasi perkembangan siswa, 2) Mengatasi hambatan perkembangan siswa pada setiap aspek perkembangan, 3) Menuntaskan ketercapaian tugas perkembangan, 4) Memfasilitasi guru Bimbingan dan Konseling dalam memberikan layanan bimbingan dan konseling.Metode kegiatan menggunakan langkah-langkah: 1) Pesiapan, yaitu dengan cara survey di lapangan, 2) Kegiatan, dengan cara pelatihan membuat paket konten, 3) Evaluasi, diberikan dengan mengumpulkan data yang diperoleh dari kegiatan pelatihan pembuatan paket konten. Hasil kegiatan dapat diidentifikasikan mengenai tingkat pemahaman peserta pengabdaian adalah $75 \%$ peserta memahami konsep pengembangan layanan paket konten, arti penting pengembangan layanan, dan menerbitkan sebuah buku bahan ajar.
\end{abstract}

Kata Kunci: Paket Konten, Guru Bimbingan dan Konseling, SMA Kubu Raya.

\begin{abstract}
The implementation of this service package aims to facilitate the teachers and students for developing every aspects in each phase of students' progress. The aims of this dedication are: 1) Facilitating and stimulating the student's progress, 2) Resolving the problem in each phase of students' progress. 3) Completing the achievement of the progressing task, 4) Facilitating the counselor in giving advice and counseling service. There are several phases that used in this activities method, such as: 1) Preparation, by survey in the field, 2) Activities, by training to create content package, 3) Evaluation, by collecting the data obtained of training activities of crating content package. The results of the activities can be identified regarding on the level of participants' understanding which is $75 \%$ participants understand about the concept of progressing content package service, the important meaning of progressing service, and publishing a material book for teaching.
\end{abstract}

Keyword: Content Package, Counselor, SMA Kubu Raya.

\section{PENDAHULUAN}

Guru Bimbingan dan Konseling (BK) merupakan pemberian layanan kepada peserta didik, baik secara perorangan maupun kelompok, agar mampu mandiri dan berkembang secara optimal dalam bidang bimbingan pribadi, sosial, belajar dan karier, melalui jenis layanan dan kegiatan pendukung berdasarkan 
norma-norma yang berlaku. (Prayitno, 2011: 11). Layanan Bimbingan dan konseling diberikan oleh guru BK dengan tugas dan tanggung jawab yang tersusun dalam program layanan bimbingan dan konseling. Salah satu layanan yang diberikan khususnya pada siswa remaja yaitu layanan penguasaan konten. Layanan Penguasaan Konten (PKO) merupakan layanan bantuan kepada individu (sendiri dan kelompok) untuk menguasai kemampuan atau kompetensi tertentu melalui proses belajar. Layanan penguasaan konten adalah salah satu jenis layanan bimbingan dan konseling yang memungkinkan siswa dapat memahami dan mengembangkan sikap dan kebiasaan belajar yang baik, keterampilan dan materi belajar yang cocok dengan kecepatan dan kesulitan belajarnya, serta tuntutan kemampuan yang berguna dalam kehidupan dan perkembangan dirinya, membantu individu menguasai aspek-aspek konten tersebut secara tersinergikan, dengan penguasaan konten, individu diharapkan mampu memenuhi kebutuhannya serta mengatasi masalah-masalah yang dihadapinya. Dengan kemampuan ataupun kompetensi itulah individu itu hidup dan berkembang. Banyak atau bahkan sebagaian besar dari kemampuan atau kompetensi itu harus dipelajari. Untuk itu individu harus belajar, dan belajar.

Permasalahan yang terjadi di Sekolah Menengah Atas Kabupaten Kubu Raya, yaitu masih kurangnya pemahaman oleh Guru Bimbingan dan Konseling tentang layanan penguasaan konten, belum menggunakan layanan yang baik bagi peserta didik dengan menggunakan teknik konsleing yang efektif dan efisien, belum mempunyai sarana untuk memfasilitasi dan menstimulasi pencegahan permasalahan yang terjadi pada peserta didik. Rencana pemecahan masalah dengan memberikan pemahaman tentang pentingnya layanan paket konten dan pelatihan kepada Guru Bimbingan dan Kegiatan cara pembuatan paket konten yang sesuai dengan perkembangan siswa.

Tujuan kegiatan ini adalah Pelaksanaan paket layanan ini bertujuan untuk memfasilitasi para guru dan siswa dalam rangka membantu perkembangan dalam setiap aspek pada fase perkembangan siswa. Berikut tujuan dari pelaksanaan paket konten bimbingan dan konseling disekolah: (1) Memfasilitasi dan menstimulasi perkembangan siswa, (2) Mengatasi hambatan perkembangan siswa pada setiap 
aspek perkembangan, (3) Menuntaskan ketercapaian tugas perkembangan, (4) Memberikan penjelasan dan pemahaman kepada siswa kebiasaan bersosialisasi yang baik.Kegiatan pengembangan paket konten bimbingan dan konseling difokuskan pada penyuluhan materi layanan yang beracuan pada tugas-tugas perkembangan anak remaja usia SMA. Sasaran objek kegiatan ini adalah berbagai literatur kepustakaan yang mendukung pengembangan materi. Sedangkan sasaran subjek kegiatan ini adalah anggota pelaksana kegiatan berkolaborasi dengan guru Bimbingan dan Konseling yang diwadahi dalam Musyawarah Guru Bimbingan dan Konseling (MGBK) SMA di Kabupaten Kubu Raya yang berjumlah 24 guru.

Kajian teori yang berkaitan dengan penguasaan konten yaitu: Yusuf (2009: 21) menjelaskan layanan penguasaan konten merupakan: Layanan bantuan kepada individu (sendiri-sendiri ataupun kelompok) untuk menguasai kemampuan ataupun kompetensi tertentu melalui kegiatan belajar. Kemampuan atau kompetensi yang dipelajari itu merupakan satu unit konten yang didalamnya terkandung fakta dan data, konsep, proses, hukum dan aturan, nilai, persepsi, afeksi, sikap, dan tindakan yang terkait didalamnya. Cicchetti, D. \& Cohen, D. J (2006: 40), Layanan penguasaan konten membantu individu menguasai aspekaspek konten membantu individu menguasai aspek-aspek konten tersebut secara tersinergikan. Dengan penguasaan konten, individu diharapkan mampu memenuhi kebutuhannya serta mengatasi masalah-masalah yang dialaminya .

Kemendikbud, (2013: 2), Layanan penguasaan konten yaitu layanan bimbingan dan konseling yang membantu peserta didik menguasai konten tertentu, terutama kompetensi dan atau kebiasaan dalam melakukan, berbuat atau mengerjakan sesuatu yang berguna dalam kehidupan di sekolah/madrasah, keluarga, dan masyarakat sesuai dengan tuntutan kemajuan dan berkarakter cerdas yang terpuji, sesuai dengan potensi dan peminatan dirinya. Layanan penguasaan konten adalah layanan bantuan kepada individu (sendiri-sendiri ataupun dalam kelompok) untuk menguasai kemampuan atau kompetensi tertentu melalui kegiatan belajar Prayitno, (2012: 30). Layanan penguasaan konten harus terdapat suatu konten atau kemampuan atau kompetensi tertentu yang dibelajarkan kepada siswa dan diharapkan siswa mampu menguasai konten tersebut secara matang. 
Penguasaan konten ini perlu bagi individu untuk menambah wawasan dan pemahaman, mengarahkan penilaian dan sikap,menguasai cara-cara kebiasaan tertentu untuk memenuhi kebutuhannya dan mengatasi masalah-masalahnya. Kedua tujuan khusus penguasaan konten dapat dilihat pertama dari kepentingan individu atau klien mempelajarinya, dan kedua isi konten itu sendiri.

Sukardi (2008: 24) mendefinisikan layanan penguasaan konten adalah layanan bimbingan dan konseling yang memungkinkan siswa memahami dan mengembangkan sikap dan kebiasaan belajar yang baik, keterampilan dan materi belajar yang cocok dengan kecepatan dan kesulitan belajarnya, serta tuntutan kemampuan yang berguna dalam kehidupan sehari-hari. Tujuan dari pemberian layanan Penguasaan konten terbagi menjadi dua.Pertama tujuan umum layanan penguasaan konten adalah dikuasainya suatu konten tertentu.

\section{METODE}

Sasaran subjek kegiatan ini adalah anggota pelaksana kegiatan berkolaborasi dengan Guru Bimbingan dan Konseling yang diwadahi dalam Musyawarah Guru Bimbingan dan konseling (MGBK) SMA di Kabupaten Kubu Raya. Pelaksanaan pengabdian dilakukan dengan tiga tahapan, dimana tahap pertama merupakan tahap persiapan. Pada tahap ini kelompok pengabdi melakukan survey pendahuluan untuk melihat kondisi di lapangan mengenai pengembangan penguasaan konten yang telah dihasilkan oleh guru BK di Kabupaten Kubu Raya. Dalam tahap ini dicari permasalahan-permasalahan yang dihadapi oleh guru BK dalam meningkatkan kemampuan pengembangan layanan penguasaan konten. Tahap selanjutnya merupakan tahapan pelaksanaan kegiatan pengabdian. Dalam tahap ini pengabdi melakukan kegiatan pengembangan layanan BK dalam bentuk pelatihan membuat penguasaan konten.

Tahap yang terakhir adalah tahap evaluasi. Pada tahap ini dilakukan evaluasi atas hasil yang telah dicapai oleh peserta pelatihan. Masukan dan perbaikan lebih lanjut dapat dilakukan pada tahap ini. Evaluasi diberikan dengan mengumpulkan data yang diperoleh dari kegiatan pelatihan pembuatan penguasaan konten. Data diambil dengan menyimpulkan pemahaman guru-guru 
BK ketika diberikan makalah yang disampaikan dengan metode ceramah dan dilanjutkan dengan tanya jawab/diskusi, serta dari hasil pengembangan penguasaan konten yang berwujud karya ilmiah baik laporan penelitian tindakan bimbingan dan konseling maupun artikel ilmiah yang dihasilkan oleh guru BK sebagai hasil dari pelatihan. Indikator ketercapaian tujuan pengabdian adalah bahwa $80 \%$ guru-guru BK sudah memahami penguasaan konten, arti penting layanan, arti penting peningkatan kualitas dan kuantitas guru BK berbentuk laporan penelitian tindakan bimbingan dan konseling maupun artikel ilmiah di bidang pendidikan.

Pelaksanaan kegiatan Pengabdian pada Masyarakat ini dikemas dengan menggunakan pendekatan workshop. Kegiatan dilakukan menggunakan metode ceramah, diskusi dan latihan. Adapun langkah-langkah dalam pelaksanaan kegiatan pengabdian ini adalah sebagai berikut: (1) Peserta pelatihan diberikan materi mengenai layanan penguasaan konten, (2) Peserta diberikan kesempatan untuk mendiskusikan materi yang telah diberikan. Kesempatan tanya jawab diberikan untuk memperjelas hal-hal yang masih menjadi keraguan, (3) Peserta berlatih untuk mengembangkan layanan penguasaan konten, (4) Peserta diberikan bimbingan pelaporan hasil penelitian layanan bimbingan dan konseling khususnya layanan penguasaan konten, (5) Hasil karya pengembangan layanan penguasaan konten dikumpulkan dan dianalisis untuk diberikan masukan dan perbaikan lebih lanjut.

\section{HASIL DAN PEMBAHASAN}

Kegiatan pengembangan paket konten bimbingan dan konseling merupakan kelanjutan dari kegiatan PPM sebelumnya. Kegiatan ini dimulaidari menyusun peta konsep paket konten, menyusun paket konten, pembahasan internal draf paket konten, Focus Group Discassion (FGD) dengan guru Bimbingan dan Konseling bersama personel MGBK Kabupaten Kubu Raya. Kegiatan pelatihan berjalan dengan lancar dihadiri 17 guru BK, dilaksanakan pada tanggal 2-5 Februari 2018. Peserta pelatihan terlihat antusias dengan materi pelatihan yang diberikan. Hal ini terlihat dari awal hingga akhir acara, semua peserta mengikuti 
dengan baik. Materi mengenai layanan penguasaan konten diberikan pada hari pertama pelatihan. Pada hari kedua peserta pengabdian melakukan workshop peningkatan pengembangan layanan penguasaan konten. Guru-guru peserta pengabdian mengidentifikasi permasalahan yang layak diangkat untuk menjadi karya tulis ilmiah berupa buku. Bagi guru yang telah melasanakan penelitian tindakan bimbingan dan konseling, kegiatan yang dilakukan adalah menyusun laporan dalam bentuk bahan ajar. Langkah-langkah dalam pelaksanaan kegiatan pengabdian ini adalah sebagai berikut: (1) Peserta pelatihan diberikan materi mengenai layanan penguasaan konten, (2) Peserta diberikan kesempatan untuk mendiskusikan materi yang telah diberikan. Kesempatan tanya jawab diberikan untuk memperjelas hal-hal yang masih menjadi keraguan, (3) Peserta berlatih untuk mengembangkan layanan penguasaan konten, (4) Peserta diberikan bimbingan pelaporan hasil penelitian layanan bimbingan dan konseling khususnya layanan penguasaan konten, (5) Hasil karya pengembangan layanan penguasaan konten dikumpulkan dan dianalisis untuk diberikan masukan dan perbaikan lebih lanjut. Hasil karya guru dikumpulkan, diberi masukan dan selanjutnya diperbaiki lagi. Selama proses penulisan dilakukan tanya jawab dan diskusi antara peserta dan pengabdi untuk meningkatkan pemahaman, sehingga akan memperoleh hasil yang diinginkan. Berdasarkan hasil kegiatan dapat diidentifikasi mengenai tingkat pemahaman peserta pengabdian adalah bahwa $75 \%$ peserta pengabdian memahami konsep pengembangan layanan penguasaan konten, arti penting pengembangan layanan dan arti penting peningkatan kualitas dankuantitas pengembangan layanan khususnya penguasaan konten diterbitkan dalam bentuk sebuah buku bahan ajar. 


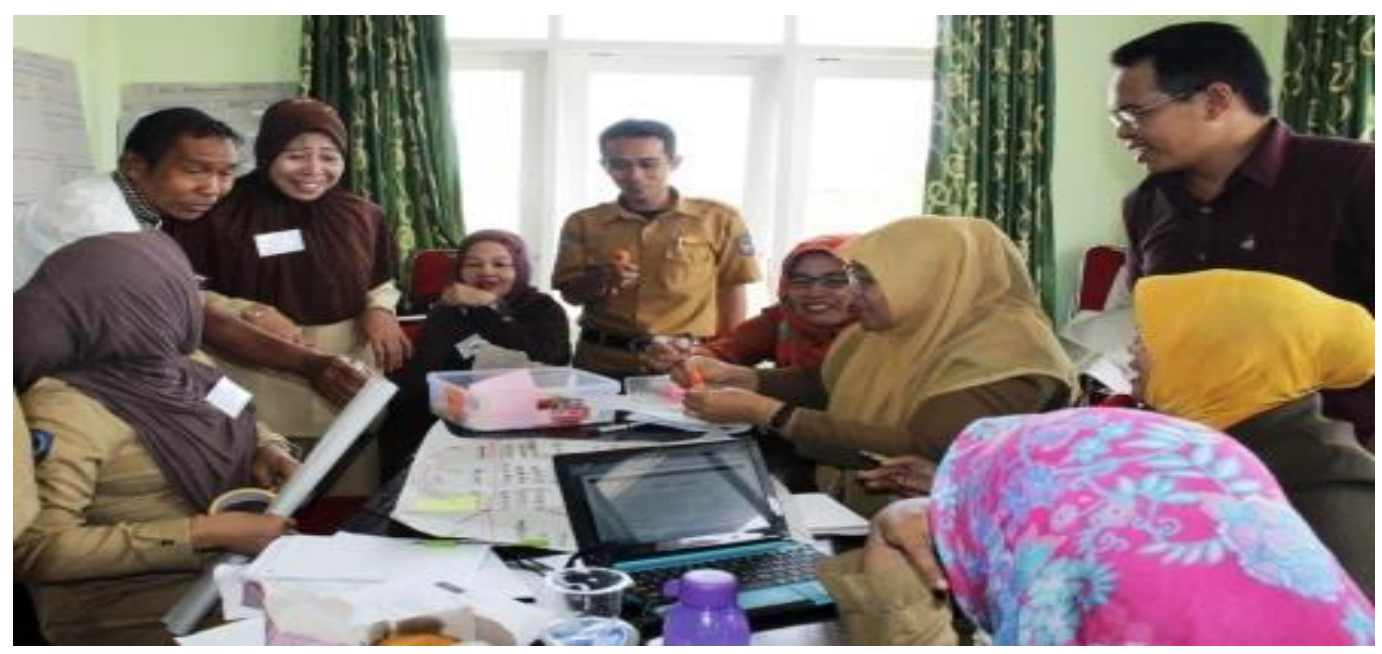

Gambar 1. Kegiatan Guru dalam Menyusun Layanan Paket Konten

Kegiatan pengabdian pelatihan pengembangan layanan penguasaan konten yang berbentuk penulisan hasil laporan penelitian tindakan bimbingan dan konseling maupun buku ajar pendidikan bagi guru BK untuk meningkatkan pemberian layanan terutama penguasaan konten dapat berjalan dengan lancar. Pelatihan pengembangan paket konten BK memang dibutuhkan bagi guru-guru BK tingkat SMA. Kebanyakan peserta mengeluhkan kurangnya pengetahuan dan pemahaman akan penyusunan paket konten dan arti pentingnya untuk meningkatkan profesionalitas sebagai guru. Guru-guru menyadari sepenuhnya bahwa paket konten penting bagi sebagai bentuk perwujudan tanggungjawab guru. Untuk itu diperlukan penelitian tindakan bimbingan dan konseling yang dapat meningkatkan kualitas pemberian layanan yang inovatif. Guru hendaknya juga bertanggungjawab atas pengembangan ilmunya. Agar ilmu yang diembannya dapat dikembangkan dan tidak tertinggal, guru seyogyanya melakukan kajian keilmuan yang menjadi bidangnya, dalam hal ini bidang BK. Hal ini akan berdampak pada peningkatan penguasaan pengetahuan dan keterampilannya sebagai seorang profesional.

Penelitian relevan tentang layanan penguasaan konten: Mohammad, Y.G (2017), dengan judul Layanan Penguasaan Konten untuk Meningkatkan Keterampilan Berbicara di Depan Umum Bagi Siswa Kemampuan berbicara di depan umum adalah hal yang penting dimiliki oleh siswa untuk dapat berinteraksi. 
Hasil dari uji statistik disimpulkan bahwa terdapat perbedaan yang signifikan kemampuan berbicara di depan umum pada siswa kelompok eksperimen yang diberikan perlakuan layanan penguasaan konten, dengan siswa kelompok kontrol yang tidak diberikan perlakuan layanan penguasaan konten.

Sigit, H (2012), dengan judul Meningkatkan Motivasi Belajar dengan layanan penguasaan konten dukungan kepustakaan berbasis TIK. Hasil penelitian terdapat perbedaan sebelum dan setelah diberikan layanan penguasaan konten dengan dukungan tampilan kepustakaan berbasis TIK. Sebelum diberikan layanan menunjukkan kategori sedang, dan sesudah diberikan perlakuan layanan menunjukkan kategori cukup tinggi. Peningkatan sebesar 10,53\% dengan ini dapat dikatakan bahwa motivasi belajar siswa SMA Negeri 2 Ungaran dapat dikatakan melalui layanan penguasaan konten dengan dukungan tampilan kepustakaan berbasis TIK.

Sartono (2014) dengan judul Peningkatan Tanggung Jawab Belajar Melalui Layanan Penguasaan Konten dengan Teknik Role Playing. Hasil penelitian bahwa layanan penguasaan konten dengan teknik role playing dapat meningkatkan tanggungjawab belajar siswa, dapat dilihat hasil pengamatan pada pelaksanaan siklus I skor rata-rata yang diperoleh 2,4 dengan hasil pengamatan masih terdapat 5 siswa yang sedang dan 7 siswa yang rendah tanggungjawab belajarnya. Pada pelaksanaan siklus II terdapat perbaikan dengan cara anggota diminta menghayati baik secara perilaku maupun ucapan seperti layaknya pemain sinetron dalam layar TV dan skenario dari peneliti tanpa diberitahu, anggota diminta memainkan peran tersebut dengan baik. Pada siklus II ini pelaksanaan layanan penguasaan konten dengan teknik role playing dapat meningkatkan tanggungjawab belajar siswa, diperoleh hasil skor rata-rata yaitu 3,6.

Zamroni, N (2015) dengan judul Meningkatkan Kemandirian Belajar Melalui Layanan Penguasaan Konten dengan Teknik Latihan Saya Bertanggungjawab. Hasil penelitian layanan penguasaan konten dengan teknik latihan saya bertanggung jawab dapat meningkatkan kemandirian belajar siswa, dapat dilihat hasil pengamatan pada pelaksanaan siklus I skor rata-rata yang diperoleh 2,5 dengan hasil pengamatan masih terdapat 5 siswa yang sedang dan 6 siswa yang 
rendah tanggungjawab belajarnya. Pada pelaksanaan siklus II terdapat perbaikan dengan cara anggota diminta menyatakan kalimat saya bertanggungjawab untuk itu dengan kompak sambil mengepalkan tangan. Pada siklus II ini pelaksanaan layanan penguasaan konten dengan teknik latihan saya bertanggungjawab dapat meningkatkan.

\section{SIMPULAN}

Secara umum kegiatan pengabdian pada masyarakat (PPM) dalam rangka "Pelaksanaan Paket Konten untuk Guru Bimbingan dan Konseling di Sekolah Menengah Atas Kabupaten Kubu Raya” berjalan dengan lancar. Adapun kegiatan yang dilaksanakan berupa: 1) Koordinasi dan sosialisasi dengan Kepala Sekolah serta jajarannya berjalan dengan lancar, 2) Pelatihan penulisan paket penguasaan konten untuk guru BK, telah terlaksana dengan baik, 3) Penyusunan layanan penguasaan konten berupa buku ajar, sudah terlaksana.

Pihak sekolah mengharapkan bahwa kegiatan ini sangat memberikan kontribusi yang positif bagi guru khususnya guru BK dalam memberikan layanan kepada siswanya. Oleh karena itu pihak sekolah sangat berharap kegiatan ini dilaksanakan secara kontinyu setiap semesternya, dan selalu memberikan manfaat bagi sekolah menengah atas di Kabupaten Kubu Raya.

\section{UCAPAN TERIMA KASIH}

Terima kasih diucapkan kepada IKIP PGRI Pontianak atas dana Pengabdian kepada Masyarakat tahun anggaran 2018 yang diberikan dan MGBK Kabupaten Kubu Raya.

\section{DAFTAR PUSTAKA}

Cicchetti, D. \&Cohen, D. J. 2006.Developmental Psychopathology: Theory and Method. Canada: Wiley.

Kemendikbud, 2013. Peraturan Mentri Pendidikan dan Kebudayaan no 81a. implementasi kurikulum 2013 lampiran IV. Jakarta: Kemendikbud.

Mohammad, Y.G. 2017Jurnal Fokus Konseling (Volume 3, Nomor 2) Jakarta: Universitas Indraprasta PGRI Jakarta. 
Prayitno, 2011. Pedoman Khusus Bimbingan dan Konseling. Jakarta: Depdiknas.

Prayitno.2012. Jenis Layanan dan Kegiatan Pendukung Konseling. Padang: Universias Negeri Padang.

Sartono.2014 Jurnal Penelitian Tindakan Kelas (Volume 16, Nomor 2) Semarang: Didaktikum.

Sigit, H. 2017. Jurnal of Guidane and Counseling (Volume 1, Nomor 1) Semarang: Unnes.

Sukardi, 2008. Pengantar Pelaksanaan Program Bimbingan dan Konseling di Sekolah. Jakarta: Rineka Cipta.

Yusuf, S. 2009. Program Bimbingan dan Konseling di Sekolah. Bandung: RIZQI Press.

Zamroni, N 2015 Jurnal Penelitian Tindakan Bimbingan dan Konseling (Volume 1, Nomor 1). Semarang: Didaktikum. 